\title{
WORLDLY ETHICS
}





\section{WORLDLY ETHICS}

$\overline{-}$

Democratic Politics and

Care for the World

\section{ELLA MYERS}

DUKE UNIVERSITY PRESS

DURHAM AND LONDON 2013 
(C) 2013 Duke University Press

All rights reserved

Printed in the United States of America on acid-free paper @

Designed by Heather Hensley

Typeset in Whitman by Tseng Information Systems, Inc.

Library of Congress Cataloging-in-Publication Data appear on the last printed page of this book. 
FOR MARK

$\overline{-}$ 
